\title{
The Analysis about Influencing Factors of Teachers' Job Performance in University
}

\author{
Zhang Rui \\ Shandong Business and Technology University \\ SDIBT \\ Yantai, China \\ (376949884@qq.com)
}

\author{
Yuan Fei \\ Shandong Business and Technology University \\ SDIBT \\ Yantai, China \\ (380076394@qq.com)
}

\begin{abstract}
In this paper, combined with the domestic and foreign scholars' analysis, we have selected and summarized the factors that influence the performance of university teachers' job. Based on the sample of $\mathbf{3 6 9}$ valid questionnaires, with the help of empirical research of statistical analysis software SPSS 17.0, we hope this paper can provide a reliable basis for mobilizing the enthusiasm of the job of college teachers, and promoting the optimization of human resource management system in universities.
\end{abstract}

Keywords-Analysis; University teachers; Job performance; Influencing factors

\section{INTRODUCTION}

As the higher education system of China continuous deepening, the increasing competition among colleges and universities are facing great changes. Teachers are playing an increasingly important role in talents training and scientific research. The quality of their performance is affect directly to the core competence of universities. But right now, there are some problems which have significantly limit the development of higher education in colleges and universities requires us to pay attention to, such as the reduction of teaching performance level, loss of sense of responsibility and lack of enthusiasm for work. So how to strength internal mechanism management, enhance the sense of mission and sense of responsibility have become an urgent problem, which can maximize the performance of teachers job, stimulate vitality of universities' development. At the present stage, the research of teachers' job performance is mainly focus on how to build job performance appraisal mechanism inside and outside the nation, but the major factors which affect college teachers' job performance are neglected.

In this paper, we choose professional instructors from three universities in Yantai as a research object, then validate the job performance influencing factor index set out above. According to the statistical results, we can put forward the corresponding strategies. We believe this initiative will mobilize the enthusiasm of the work of teachers in colleges, promote the optimization of human resource management system in colleges and universities, improve the quality of higher education. This article's research result is significant in both theory and reality.

\section{RELEVANT INFLUENCING FACTORS SCREENING}

Based on a foreign scholar--- Vroom's(1964) opinion, job motivation and ability can make an affect on personal performance[1],Blumberg etc(1982) added that opportunity, ability and excitation had a common influence on job performance[2]. Individual factor and environmental factor were the major factors of employee performance model, Gardy etc(1994) said[3].

Combined with performance management theory, domestic scholars, include Xiangping $\mathrm{Wu}$, proposed that summarized from the research of individual, organization and job, they believed work environment, organizational commitment and human resource management level were the major factors of job performance[4].Considering from individual, universities, job and society, Wenyan Chen(2015)found out that the major factors of job performance can be concluded as knowledge ,skills, positive mental ability of individual, support of leadership team, organizational commitment etc[5].Dongmei Sun(2014) summarized that sense of organizational identity, management mode of colleges and universities, job pressure, development opportunities of professional teachers and campus culture can make an great difference on teachers' job performance[6]. Through data analysis, professor as Xingchun $\mathrm{Xu}$ (2011)made an conclusion that there was a significant positive correlation between teachers' job values and job performance[7]; In 2008,Zhaotou Zhou showed in his study that achievement motivation of university teachers had a positive effect on their job performance[8].

Through the analysis of relevant research at here and abroad ,combined with theoretical research on performance management of domestic and foreign analysis of relevant research at the meanwhile, this paper have discussed the factors which affect job performance of teachers of universities from three aspects---individuals, organization and job. As for individuals, there are three dimensions of them, individual achievement motivation, individual knowledge skills and individual value; organizational culture, organizational support and organizational commitment are conclude as organization level. Last but not the least, there are also two dimensions of job, job opportunity and job pressure. 


\section{QuestionnAire Design AND Data Collection}

\section{A. Questionnaire Design}

This paper is compiled through three parts, literature research, internal communication and discussion of academic team, and preliminary research of questionnaire, modify the various problems in the questionnaire at the meanwhile, and then the final questionnaire is completed. In spite of basic information of teachers, the extra parts are measured by Li Kete (Likert) 5 point scale.

\section{B. Questionnaire Distribution and Recovery}

Through the research concluded from professional instructors who are chosen from three universities in Yantai as a research object, we obtain the required data from two forms ,paper questionnaire and electronic questionnaire. After a rigorous screening, delete some invalid questionnaire such as the questionnaires with high missing value and the whole column select repeat answer item, we get 369 effective questionnaires totally.

\section{Data Analysis Tool}

Statistical analysis software SPSS 17.0

\section{ReSUlts AND Discussion}

\section{A. Reliability and Validity Analysis}

The reliability of this paper is tested by Cronbach's $\alpha$ coefficient test and common factor analysis test. The results are shown in table I. As we can see, items in the questionnaire have high reliability and validity for each variable.

TABLE I. THE RESULT OF RELIABILITY AND VALIDITY ANALYSIS

\begin{tabular}{|c|l|l|l|}
\hline variable & Cronbach & KMO & $\begin{array}{c}\text { Total Variance } \\
\text { Explained } \\
(\%)\end{array}$ \\
\hline $\begin{array}{c}\text { individual achievement } \\
\text { motivation }\end{array}$ & .759 & .669 & 67.965 \\
\hline $\begin{array}{c}\text { individual knowledge } \\
\text { skills }\end{array}$ & .763 & .673 & 67.942 \\
\hline individual value & .790 & .674 & 70.987 \\
\hline organizational culture & .769 & .650 & 68.930 \\
\hline organizational support & .804 & .666 & 72.168 \\
\hline $\begin{array}{c}\text { organizational } \\
\text { commitment }\end{array}$ & .744 & .686 & 66.385 \\
\hline job opportunity & .649 & .643 & 62.760 \\
\hline job pressure & .871 & .610 & 79.877 \\
\hline job performance & .848 & .705 & 76.710 \\
\hline & \multicolumn{2}{|l}{} \\
\hline
\end{tabular}

\section{B. Correlation Analysis}

Through the Pearson correlation analysis, we make a conclusion preliminary of the relationship between influencing factors and job performance. As we can see in table II , there are eight factors involved in three concepts, they are all have positive correlation at 0.01 significant level.
However, Pearson correlation analysis can only make a preliminary determination of the correlation between variables, the causal relationship between variables can not be explained. Based on this study, the path analysis is introduced.

TABLE II. PEARSON CORRELATION ANALYSIS BETWEEN INFLUENCING FACTORS AND JOB PERFORMANCE

\begin{tabular}{|c|c|c|c|}
\hline & & $\begin{array}{c}\text { individual } \\
\text { achievement } \\
\text { motivation }\end{array}$ & $\begin{array}{c}\text { individual } \\
\text { knowledge skills }\end{array}$ \\
\hline \multirow{3}{*}{$\begin{array}{c}\text { job } \\
\text { performance }\end{array}$} & $\begin{array}{c}\text { Pearson } \\
\text { Correlation }\end{array}$ & $.840 * *$ & $.775 * *$ \\
\hline & Sig.(2-tailed) & .000 & .000 \\
\hline & & $\begin{array}{l}\text { individual } \\
\text { value }\end{array}$ & $\begin{array}{c}\text { organizational } \\
\text { culture }\end{array}$ \\
\hline \multirow{2}{*}{$\begin{array}{c}\text { job } \\
\text { performance }\end{array}$} & $\begin{array}{c}\text { Pearson } \\
\text { Correlation }\end{array}$ & $.797 * *$ & $.927 * *$ \\
\hline & Sig.(2-tailed) & .000 & .000 \\
\hline & & $\begin{array}{l}\text { organizational } \\
\text { support }\end{array}$ & $\begin{array}{c}\text { organizational } \\
\text { commitment }\end{array}$ \\
\hline \multirow{2}{*}{$\begin{array}{c}\text { job } \\
\text { performance }\end{array}$} & $\begin{array}{c}\text { Pearson } \\
\text { Correlation }\end{array}$ & $.942 * *$ & $.665 * *$ \\
\hline & Sig.(2-tailed) & .000 & .000 \\
\hline & & job opportunity & Job pressure \\
\hline \multirow{2}{*}{$\begin{array}{c}\text { job } \\
\text { performance }\end{array}$} & $\begin{array}{c}\text { Pearson } \\
\text { Correlation }\end{array}$ & $.867 * *$ & $.619 * *$ \\
\hline & Sig.(2-tailed) & .000 & .000 \\
\hline
\end{tabular}

**. Correlation is significant at the 0.01 level (2-tailed).

\section{Path Analysis}

The result of path analysis is shown in table III, besides job pressure, the rest of factors have a great influence on job performance. Among these factors, organizational support

$$
\left(\gamma_{22}=0.363\right) \text { 、organizational culture }\left(\gamma_{21}=0.242\right) \text { 、 }
$$

individual achievement motivation $\left(\gamma_{11}=0.131\right)$ 、 job opportunity $\left(\gamma_{31}=0.130\right)$ are the most outstanding factors which effect the performance of teachers from universities, the significant level was 0.01 . Individual value $\left(\gamma_{13}=0.108\right)$ 、 individual knowledge skills $\left(\gamma_{12}=0.074\right)$ 、 organizational commitment $\left(\gamma_{23}=0.054\right)$ are significant at 0.05 level. 
TABLE III. COEFFICIENTS

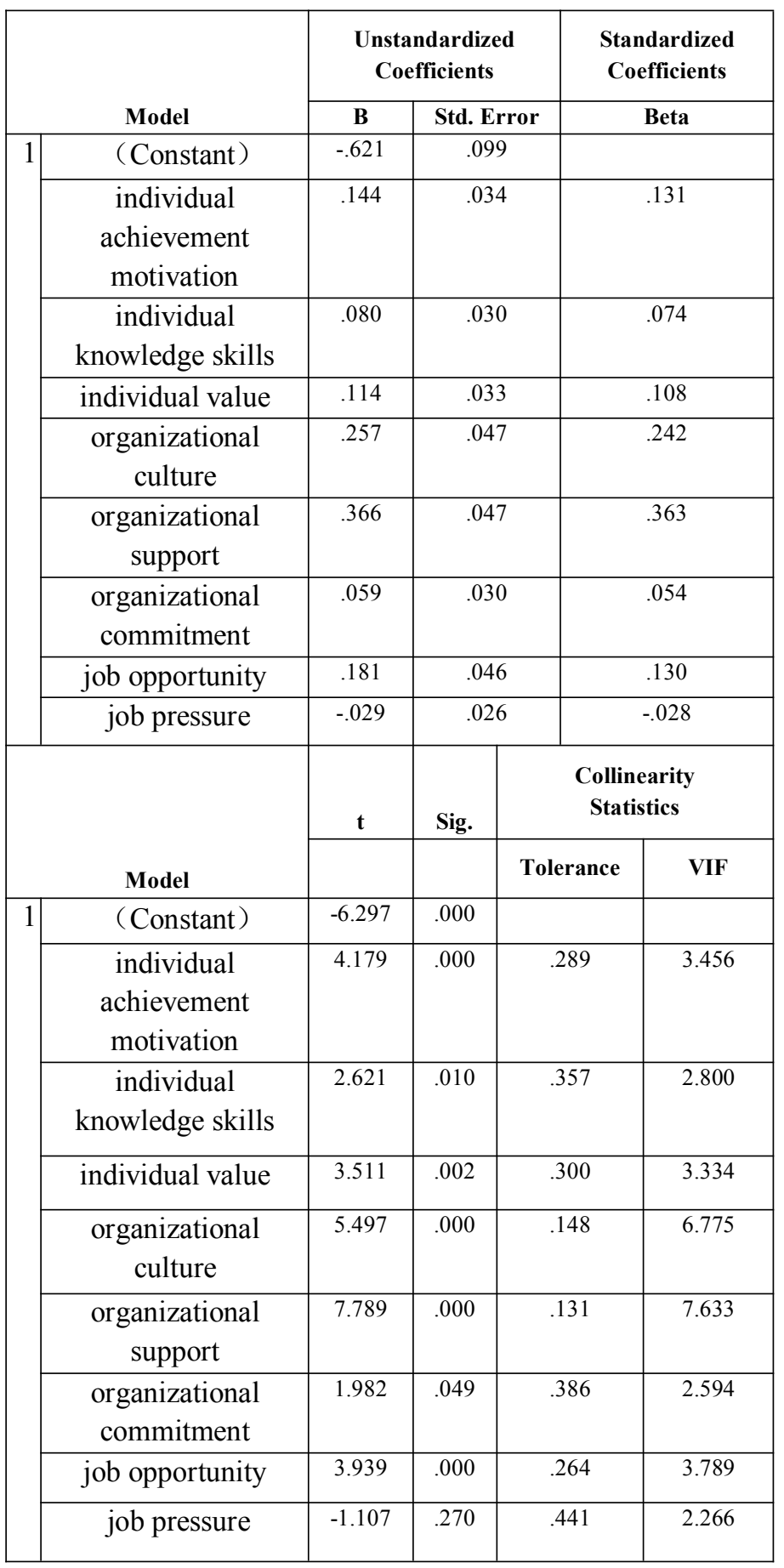

a. Dependent Variable : job performance

\section{Conclusion And Countermeasure}

Empirical results show that the eight factors that influence the job performance of college teachers, except job pressure, the remaining seven factors are showing significant positive effect on job performance. Therefore, this study can improve the performance of university teachers' job through the following two ways: (1) Colleges and universities should provide teachers with all kinds of professional skills training opportunities, the ability and level of all aspects should be taken into account in the selection of talents. At the same time, universities should pay attention to the guidance and cultivation of teachers' achievement motivation and values, to lead them to set up lofty morality and academic reputation, stimulate teachers' consciousness of teaching and scientific research; (2) Universities should establish appropriate management mode, create an inspiring campus culture, pay more attention to the physical and mental health of teachers at the meantime, implement targeted management and intervention, in order to build a democratic and open learning environment, enhance the sense of belonging and identity of the organization.

\section{ACKNOWLEDGMENT}

On the completion of my thesis, I should like to express my deepest gratitude to all those whose kindness and advice have made this work possible. I am greatly indebted to my advisor Keying Zhang, who gave me valuable instructions and has improved me in language. Her effective advice, shrewd comments have kept the thesis in the right direction.

I would like to thank my partner Fei Yuan and Wei Jiao for their friendship and constructive suggestions, they constantly encouraged me when I felt frustrated with this dissertation.

\section{REFERENCES}

[1] Vroom,V.H. Work and Motivation[M]. New York:John Well Eyand Son, 1964.

[2] Blumberg,M. and Pringle,C.C. The Missing Opportunity in Organizational Research:Some Implications for a Theory of Work Performance[J]. Academy of Management Review,1982(7):560-569.

[3] Shengjun Chen. Peripheral performance theory and practice[M]. Foreign economic and trade university press,2007. (In Chinese)

[4] Xiangping $\mathrm{Wu}$, Fuyuan $\mathrm{Xu}$, Yong Zhou. Analysis of Influencing Factors of University Teachers' Job Performance[J]. Journal of East China Normal University(Educational Sciences), 2006,24(1):30-37. (In Chinese)

[5] Weiyan Sun, Qiang Li, Zhining Wang. Research on the University Teacher's Job Performance and its Influencing Factors [J].Technology Economy and Management Research, 2015,(3):9-13. (In Chinese)

[6] Dongmei Sun, Xia Chen. Hybrid Research on Influencing Factor of University Teachers' Job Performance $[\mathrm{J}]$. Contemporary Teacher Education,2014, 7(2):9-12. (In Chinese)

[7] Xingchun Xu, Dajun Zhang. Relationship Study on the Teachers' Work Values and Job Performance [J]. Journal of Psychological Science, 2011, 34(4):871-874. (In Chinese)

[8] Zhaotou Zhou.Empirical Research on Teachers' Achievement Motivation and Job Performance Relationship on University [J]. Modern University Education ,2008. (4):80-85. (In Chinese) 